\title{
Association of Serum Triglyceride-to-High-density Lipoprotein Cholesterol Ratio with Insulin Resistance and Non-alcoholic Fatty Liver Disease in Children and Adolescents
}

\section{Çocuk ve Ergenlerde Serum Trigliserid Yüksek-yoğunluklu Lipoprotein Kolesterol Oranının Insülin Direnci ve Alkolik Olmayan Yağlı Karaciğer Hastalığında Tanısal Değeri}

\author{
Ala Üstyol, Funda Kökali, Nilgün Selçuk Duru, Murat Elevli \\ University of Health Sciences, Haseki Training and Research Hospital, Clinic of Child and Health and Diseases Endocrinology, Istanbul, Turkey
}

Abstract

Aim: Insulin resistance (IR) is considered the main contributor to non-alcoholic fatty liver disease (NAFLD). Triglyceride (TG)-to-highdensity lipoprotein cholesterol (HDL-C) ratio (TG/HDL-C) has been recommended as a surrogate index of IR. However, the association between TG/HDL-C and NAFLD is as yet unclear. The aim of this study was to investigate the association of $T G / H D L-C$ ratio with $I R$ and NAFLD.

Methods: The study population included 228 obese children and adolescents (59\% girls, mean age: $12.52 \pm 2.94$ years) and 46 lean subjects ( $57 \%$ girls, mean age: $12.53 \pm 3.30$ years). The obese group was further stratified on the basis of NAFLD.

Results: The TG/HDL-C ratio was higher in obese subjects compared with controls. The NAFLD group also had a significantly higher TG/ HDL-C ratio (3.20 \pm 1.9 vs. $2.35 \pm 1.09$ ) than the non-NAFLD group. The TG/HDL ratio was correlated with alanine aminotransferase, cholesterol, glucose-to-insulin ratio (FIGR), homeostasis model assessment of IR (HOMA-IR), quantitative insulin-sensitivity check index, and insulin. A cut-off value of 2.27 was used to define a high TG/HDL-C ratio. At multivariate logistic regression analysis, FIGR [odds ratio $(O R)=4.20$ ], HOMA-IR (OR=4.15), TG/HDL-C ratio $(\mathrm{OR}=2.8)$, HDL-C $(\mathrm{OR}=2.12)$, and ALT $(O R=6.37)$ were associated with NAFLD.

Conclusion: TG/HDL-C ratio is associated with various well-defined risk factors for NAFLD, and a value of $>2.27$ may be useful in identifying children at high risk for the condition.

Keywords: Triglyceride-to-high-density lipoprotein cholesterol ratio, insulin resistance, nonalcoholic fatty liver disease, obese, children
Amaç: İnsülin direnci (ID) alkolik olmayan karaciğer hastalığı (AOYKH) için başlıca risk faktörü olarak değerlendirilmektedir. Trigliserid/ yüksek yoğunluklu lipoprotein kolesterol oranı (TG/HDL-K) iD yerine kullanılabilen bir indeks olarak tanımlanmıştır. TG/HDL-K oranının AOYKH'da tanısal değeri ile ilgili çalışmalar ise sınırlıdır. Bu çalışmanın amacı TG/HDL-K oranının iD ile AOYKH'deki tanısal değerinin belirlenmesidir.

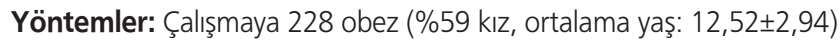

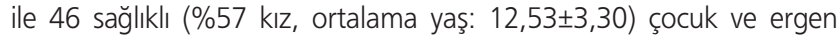
dahil edildi. Obez hasta grubu ultrason verilerine göre AOYKH olan ve olmayanlar olmak üzere iki alt gruba ayrıldılar.

Bulgular: Obez grubun TG/HDL-K oranı sağlıklı grupla kıyaslandığında anlamlı oranda yüksek bulundu. Obez grup içinde de AOYKH olanlar $(3,20 \pm 1,9)$ olmayanlara göre $(2,35 \pm 1,09)$ yüksek TG/HDL-K oranına sahiptiler. TG/HDL-K oranı ile alanin aminotransferaz, kolesterol, glukoz insülin oranı, homeostaz model değerlendirmesi-IR (HOMA-IR), kantitatif insülin hassasiyet indeksi ve insülin seviyesi arasında anlamlı korelasyon olduğu görüldü. TG/HDL-K oranının 2,27'nin üzerinde olması yüksek olarak kabul edildi. Çok değişkenli bir analiz modelinde (yaş, cinsiyet, ergenlik durumu ve beden kitle indeksine göre ayarlama yapıldıktan sonra) AOYKH üzerine yüksek glukoz insülin oranı [olasılık oranı $(\mathrm{OR})=4,20]$, HOMA-IR $(\mathrm{OR}=4,15)$, HDL $(\mathrm{OR}=2,12)$, ALT $(\mathrm{OR}=6,37)$ ve TG/HDL-K oranının $(\mathrm{OR}=2,8)$ bağımsız etkili olduğu bulundu.

Sonuç: $A O Y K H$ için iyi bilinen risk faktörleri ile TG/HDL-K arasında anlamlı korelasyon vardır. TG/HDL-K oranı için $>2,27$ eşik değeri çocuklarda AOYKH için bağımsız bir risk faktörüdür.

Anahtar Sözcükler: Trigliserid/yüksek yoğunluklu lipoprotein oranı, insülin direnci, alkolik olmayan karaciğer yağlanması, obezite, çocuklar
Address for Correspondence/Yazışma Adresi: Ala Üstyol

University of Health Sciences, Haseki Training and Research Hospital, Clinic of Child and Health and Diseases Endocrinology, istanbul, Turkey

E-mail: alaustyol@gmail.com ORCID ID: orcid.org/0000-0001-7903-7356

Received/Geliş Tarihi: 6 April 2017 Accepted/Kabul Tarihi: 9 November 2017
${ }^{10}$ Copyright 2017 by The Medical Bulletin of University of Health Sciences Haseki Training and Research Hospital
The Medical Bulletin of Haseki published by Galenos Yayınevi.

'Telif Hakkı 2017 Sağlık Bilimleri Üniversitesi Haseki Eğitim ve Araşıırma Hastanesi Haseki Tıp Bülteni, Galenos Yayınevi tarafından basıımıştır. 


\section{Introduction}

Increasing levels of obesity have led to nonalcoholic fatty liver disease (NAFLD) becoming the most common chronic liver disease (1). A close relationship exists between NAFLD and elements of metabolic syndrome; high fasting glucose, hypertension, central obesity, insulin resistance (IR), and atherogenic dyslipidemia (2). One previous study reported a 6-fold higher risk of atherosclerosis in pediatric patients with steatosis compared to that in non-steatotic subjects (3). Prompt evaluation of arterial injury is essential if subsequent vascular risk is to be avoided, because early detection and intervention permit the reversal of subclinical atherosclerosis (4). Lipoprotein ratios are considered to be of greater use than isolated lipid values in the assessment of cardiovascular risk in adult patients, since these constitute a more accurate reflection of the interactions between lipid fractions (5). Although NAFLD is known to be a major risk factor for cardiovascular disease, there has been little investigation of the clinical value of lipid ratios in this condition, particularly in the pediatric age group (6-9). Studies concerning IR and triglyceride(TG)-to-high-density lipoprotein cholesterol (HDL-C) ratio (TG/HDL-C) have revealed a clear association between them, and TG/HDL ratio was found to be significantly correlated with IR (10). Giannini et al. (11) proposed a TG/ $\mathrm{HDL}$ ratio greater than 2.27 as a significant cut-off point for predicting IR. We hypothesized that a TG/HDL-C ratio of 2.27 recommended in the context of IR might also be a good marker in NAFLD owing to this close relationship between NAFLD and IR.

\section{Methods}

\section{Study Population}

Two hundred twenty-eight children and adolescents (134 girls and 94 boys, with a mean age of $12.52 \pm 2.94$ years), who were admitted to our department between January 2015 and April 2016 because of obesity, were included in the study. Forty six age-matched healthy lean children and adolescents (26 girls and 20 boys, mean age: $12.53 \pm 3.30$ years) having a body mass index (BMI) between the $3^{\text {th }}$ and the $85^{\text {th }}$ percentile served as controls. They were enrolled among non-obese healthy subjects with no history of chronic disease and no drug treatment who attended the hospital for minor illnesses such as a common cold, conjunctivitis or similar mild afflictions. The obese group was further stratified based on NAFLD as revealed by ultrasonography. Weight was measured by a balance beam medical scale and height using a rigid stadiometer. All patients had BMI values higher than the 95th percentile based on percentile curves applicable to Turkish children (12). Puberty was evaluated using the Tanner staging criteria $(13,14)$. Blood pressure (BP) was measured with a sphygmomanometer following a 10min rest. Waist circumference (WC) was measured as a surrogate index of central obesity. Exclusion criteria included diabetes, any condition affecting insulin's action, familial or secondary dyslipidemia other than resulting from obesity, a history of alcohol use and use of drugs known to induce NAFLD. This study was approved by Haseki Training and Research Ethics Committee for Clinical Investigations (approval number: 359).

\section{Laboratory Tests}

Glucose, lipid profile, alanine aminotransferase (ALT) and insulin were analyzed in all participants following 12-h fasting. Blood glucose levels were determined using the glucose oxidase test and plasma insulin levels via electrogenerated chemiluminescence immunoassay (Unicell DXI; Beckman Coulter, USA), while calculation of serum lipid profiles was based on enzymatic methods.

\section{Definitions}

IR markers were calculated from fasting glucose and insulin values by the quantitative insulin sensitivity check index (QUICKI), fasting glucose/insulin ratio (FGIR) and the homeostasis model assessment of IR (HOMA-IR). Central obesity was defined as $W C \geq 90^{\text {th }}$ percentile (15). High $\mathrm{BP}$ was defined as systolic or diastolic $\mathrm{BP} \geq 90^{\text {th }}$ percentile (16). Glucose levels $\geq 100 \mathrm{mg} / \mathrm{dL}$ were evaluated as representing impaired fasting glucose. IR was defined as a HOMA-IR score of higher than 2.5 in prepubertal subjects and 3.16 in pubertal individuals (17). Cut-off levels of 0.357 and seven were defined for QUICKI and FIGR, respectively (18). Cut-off points recommended by the guidelines for atherogenic risk reduction in childhood were used to define dyslipidemia (19). High ALT levels were defined using sex-related cutoff points $(30 \mathrm{IU} / \mathrm{L}$ in males and $19 \mathrm{IU} / \mathrm{L}$ in females), as defined in previous studies (20). A high TG/HDL-C ratio was defined as more than 2.27. Liver ultrasonography results were used in the assessment of NAFLD.

For the statistical analysis, qualitative variables were compared using $\chi^{2}$ test and continuous variables were compared using t-tests or the Mann-Whitney $U$ test when needed. Univariate correlation analyses were performed using Spearman's correlation coefficient. After adjusting for covariates [age, sex, pubertal status, BMI- standard deviation scores (SDS)], multivariate logistic regression analysis was performed to identify independent correlates of NAFLD. Receiver operating characteristic (ROC) curve analysis was used to determine cut-off values of TG/ HDL-C ratio with maximum sensitivity and specificity for the diagnosis of NAFLD and IR. A p value of less than 0.05 was considered statistically significant. 


\section{Results}

This study involved 228 obese and 46 healthy children/adolescents. Two subgroups were established among the obese patients, depending on the presence or absence of NAFLD. The prevalence of NAFLD was 35\% in the obese study population. The groups' clinical and laboratory findings are compared in Table 1. There were no differences in sex or pubertal status among the groups.

Obese patients either with or without NAFLD exhibited significantly higher BMI-SDS than the controls. The TG/ $\mathrm{HDL}-\mathrm{C}$ ratio was also significantly higher in the non-NAFLD and NAFLD groups than in the control group $(p<0.001)$ (Figure 1). WC and systolic-diastolic BP values were lower in the control group compared to obese patients with or without NAFLD. Lower ALT, fasting insulin, TGs and HOMA-IR measurements were also determined in the control group, than in the obese patients with or without NAFLD. Fetal growth restriction (FGR) and Quick index and

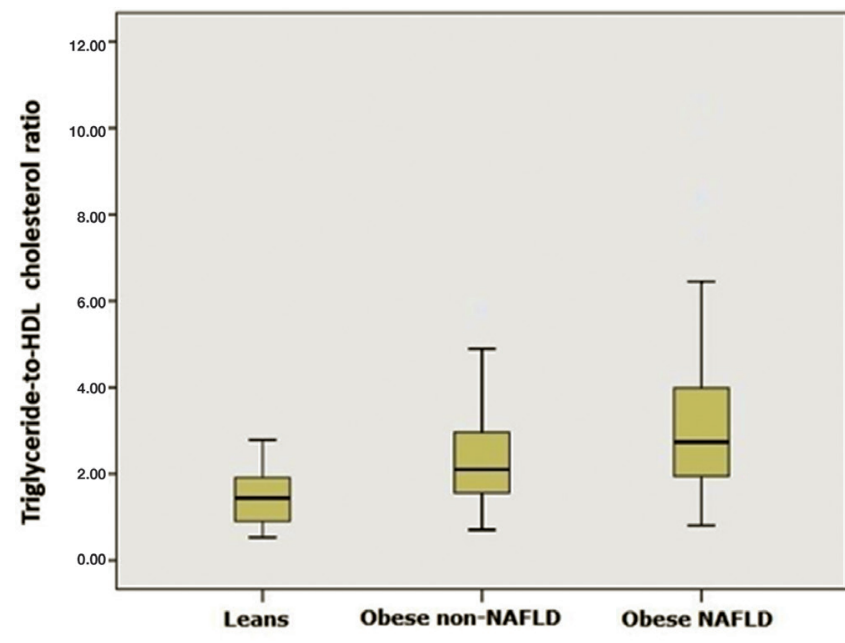

Figure 1. Comparison of Triglycerides/High density lipoprotein cholesterol ratio levels among the groups

HDL: High density lipoprotein, NAFLD: Nonalcoholic fatty liver disease

\section{Table 1. Characteristics of control and obese children with or without nonalcoholic fatty liver disease}

\begin{tabular}{|c|c|c|c|}
\hline & Control & Non-NAFLD & NAFLD \\
\hline Number of subjects & 46 & 148 & 80 \\
\hline Sex (\%) F/M & $56 / 44$ & $60 / 40$ & $56 / 44$ \\
\hline Pubertal status, n (\%) & $30(67)$ & $110(74)$ & $67(84)$ \\
\hline Age, years & $12.53 \pm 3.30$ & $12.53 \pm 3.08$ & $12.52 \pm 2.69$ \\
\hline $\mathrm{BMI}, \mathrm{kg} / \mathrm{m}^{2}$ & $19.04 \pm 2.81$ & $28.90 \pm 4.54^{\ddagger}$ & $31.14 \pm 4.57^{\star \dagger}$ \\
\hline BMI-SDS & $-0.15 \pm 0.80$ & $2.45 \pm 0.64 \ddagger$ & $2.66 \pm 0.54^{\star \dagger}$ \\
\hline Waist circumference, $\mathrm{cm}$ & $68.62 \pm 9.13$ & $95.84 \pm 12.78^{\ddagger}$ & $101.15 \pm 12.31^{\star \dagger}$ \\
\hline Systolic BP, mmHg & $104.83 \pm 12.83$ & $117.52 \pm 14.76^{\ddagger}$ & $122.77 \pm 13.66^{\star \dagger}$ \\
\hline Diastolic BP, mmHg & $62.64 \pm 7.26$ & $75.65 \pm 10.38^{\ddagger}$ & $78.62 \pm 9.85^{\star \dagger}$ \\
\hline Fasting glucose, mg/dL & $89(75-104)$ & $91(77-128)$ & $91(79-117)$ \\
\hline FGIR & $15.2(6.4-57.4)$ & $8.7(1.4-41.5)^{\ddagger}$ & $5.8(0.8-61)^{\star \dagger}$ \\
\hline$A L T, U / L$ & $13(4-42)$ & $17(2-58)^{\ddagger}$ & $26(8-195)^{\star \dagger}$ \\
\hline Total cholesterol, mg/dL & $157.63 \pm 27.18$ & $160.14 \pm 30.86$ & $165.86 \pm 32.28$ \\
\hline Triglycerides, mg/dL & $68(28-131)$ & $95(39-229)^{\ddagger}$ & $119(44-364)^{\star \dagger}$ \\
\hline LDL- cholesterol & $91.65 \pm 22.65$ & $94.10 \pm 26.70$ & $96.41 \pm 26.61$ \\
\hline HDL- cholesterol & $52(35-72)$ & $45(25-78)^{\ddagger}$ & $43(22-73)^{\star+}$ \\
\hline TG/HDL-C ratio & $1.44(0.53-2.79)$ & $2.10(0.71-5.84)^{\ddagger}$ & $2.73(0.81-10.60)^{\star \dagger}$ \\
\hline Fasting insulin, $\mu \mathrm{U} / \mathrm{mL}$ & $5.9(1.6-13.8)$ & $10.2(2.3-81.3)^{\ddagger}$ & $15.2(1.4-129.9)^{\star \dagger}$ \\
\hline HOMA-IR values & $1.25(0.3-3.0)$ & $2.3(0.5-24.1)^{\ddagger}$ & $3.5(0.3-35.6)^{* \dagger}$ \\
\hline QUICKI & $0.36(0.32-0.47)$ & $0.33(0.25-0.42)^{\ddagger}$ & $0.31(0.24-0.46)^{\star \dagger}$ \\
\hline
\end{tabular}


HDL-cholesterol levels were lower in the non-NAFLD and NAFLD groups compared with the control group. There were no differences in fasting glucose, total cholesterol or LDL cholesterol levels among the groups.

The TG/HDL-C ratio in the NAFLD group $(3.20 \pm 1.9$ vs. $2.35 \pm 1.09$ ) was significantly higher than that in the non-NAFLD group. The members of the NAFLD group also exhibited higher BMI-SDS, WC, systolic-diastolic BP, fasting insulin, TGs, ALT, and HOMA-IR measurements than non-

\begin{tabular}{|c|c|c|}
\hline & $r$ & $p$ \\
\hline BMI & 0.330 & $<0.001$ \\
\hline BMI-SDS & 0.291 & $<0.001$ \\
\hline Waist circumference & 0.343 & $<0.001$ \\
\hline Systolic BP & 0.217 & 0.001 \\
\hline Diastolic BP & 0.217 & 0.001 \\
\hline Glucose & 0.095 & 0.126 \\
\hline FGIR & -0.428 & $<0.001$ \\
\hline ALT & 0.265 & $<0.001$ \\
\hline Total cholesterol & 0.150 & 0.015 \\
\hline Triglycerides & 0.938 & $<0.001$ \\
\hline LDL-cholesterol & 0.048 & 0.435 \\
\hline HDL-cholesterol & -0.628 & $<0.001$ \\
\hline Insulin & 0.428 & $<0.001$ \\
\hline HOMA-IR & 0.422 & $<0.001$ \\
\hline QUICKI & -0.422 & $<0.001$ \\
\hline \multicolumn{3}{|c|}{$\begin{array}{l}\text { BMI: Body mass index, BMI-SDS: Body mass index-standard deviation } \\
\text { scores, BP: Blood pressure, FGIR: Fasting glucose/insulin ratio, ALT: Alanine } \\
\text { aminotransferase, HOMA-IR: Homeostasis model assessment of insulin } \\
\text { resistance, QUICKI: Quantitative insulin sensitivity check index, LDL: Low-density } \\
\text { lipoprotein, HDL: High-density lipoprotein }\end{array}$} \\
\hline
\end{tabular}

Table 3. Adjusted ${ }^{*}$ odds ratio $(95 \%$ confidence intervals) of triglyceride-to-high-density lipoprotein cholesterol ratio and other metabolic parameters for nonalcoholic fatty liver disease

\begin{tabular}{|l|l|l|l|}
\hline & OR & $\mathbf{9 5 \%} \mathbf{C l}$ & $\mathbf{p}^{*}$ \\
\hline Central obesity & 1.16 & $0.35-3.87$ & 0.808 \\
\hline Elevated blood pressure & 1.30 & $0.65-2.58$ & 0.450 \\
\hline IFG & 0.76 & $0.32-1.79$ & 0.541 \\
\hline Low FGIR & 4.20 & $2.04-8.63$ & $<0.001$ \\
\hline High HOMA-IR & 4.15 & $2.05-8.41$ & $<0.001$ \\
\hline Low QUICKI & 2.19 & $0.85-5.60$ & 0.101 \\
\hline High TG/HDL ratio & 2.80 & $1.45-5.39$ & 0.002 \\
\hline High TG & 1.92 & $0.98-3.74$ & 0.055 \\
\hline Low HDL-C & 2.12 & $1.04-4.29$ & 0.037 \\
\hline "Adustor & & &
\end{tabular}

*Adjusted for age gender. pubertal status and body mass index-standard deviation scores. FGIR: Fasting glucose/insulin ratio, HOMA-IR: Homeostasis model assessment of insulin resistance, QUICKI: Quantitative insulin sensitivity check index, TG: Triglycerides, TG/HDL: Triglycerides/high density lipoprotein, HDL-C: High density lipoprotein cholesterol, $\mathrm{Cl}$ : Confidence interval, OR: Odds ratio
NAFLD patients. FGR, Quick index and HDL-cholesterol were significantly lower in NAFLD patients compared with that in non-NAFLD patients.

In terms of IR parameters, with the exception of fasting glucose $(r=0.095)$, all parameters (insulin, $F G I R$, QUICKI, HOMA-IR) were correlated with the TG/HDL-C ratio. Significant correlations with the TG/HDL-C ratio are shown in Table 2.

Multivariate logistic regression analysis, with appropriate adjustment for age, sex, pubertal status, and BMI-SDS, was employed to identify risk factors for NAFLD, including TG/HDL-C ratio. Among the known metabolic risk factors, IR, high FGR and low HDL-C, and high ALT were associated with a 2.12-6.30-fold greater risk of NAFLD; high TG/HDL-C also increased the risk of NAFLD within that range, at 2.8-fold (Table 3).

A value of 2.27 was used to dichotomize the patients' TG/HDL-C ratio as either above or below 2.27. ROC analysis revealed $64 \%$ sensitivity and $68 \%$ specificity for this value, with an area under the ROC curve (AUROC) of 0.641 (Figure 2). This cut-off exhibited $69 \%$ sensitivity and $63 \%$ specificity in detecting the presence of IR [AUROC= 0.680 (95\% confidence interval 0.604-0.755)].

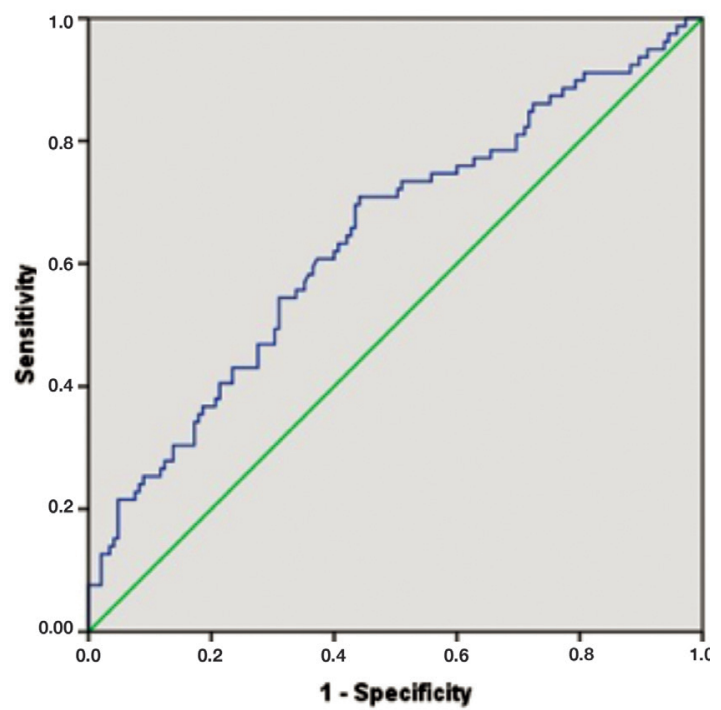

Figure 2. Receiver operating characteristic curve for the Triglycerides/ High density lipoprotein cholesterol ratio in predicting the presence of nonalcoholic fatty liver disease. Area under the receiver operating characteristic curve $=0.641$ (95\% confidence interval 0.564-0.718)

\section{Discussion}

This study revealed that high TG/HDL-C was correlated with a high risk for NAFLD together with low HDL, high ALT, and IR, which are known to be closely associated with NAFLD. This relationship was independent of obesity, age, sex, and pubertal status. This is also of potential significance 
in the context of cardiovascular risk because NAFLD is regarded as a marker of cardiovascular abnormalities.

One prospective study of children determined that the degree of atherosclerotic lesions on the intimal surface was significantly correlated with increased total cholesterol, low-density lipoprotein cholesterol and TG, and with decreased HDL-C levels (21). Studies involving adults have shown that ratios of lipoproteins to one another are more effective in assessing cardiovascular risk than lipoproteins by themselves. TG/HDL-C ratio is known to be especially useful in predicting cardiovascular risk and metabolic syndrome $(22,23)$. Although NAFLD constitutes the hepatic constituent of metabolic syndrome (24) and is a significant atherogenic risk factor even from childhood, there has been little previous investigation of the relationship between the NAFLD and TG/HDL-C ratio in the pediatric population (6-9). Nobili et al. (7) reported that NAFLD activity and fibrosis scores were significantly positively correlated with TG/HDL-C ratios in children with NAFLD confirmed by liver biopsy. The authors also determined that compared with other lipid ratios (cholesterol/HDL and LDL/HDL), the TG/HDL ratio most accurately predicted advanced liver disease. Pacifico et al. (8) stratified subjects into consecutive TG/HDL-C tertiles. Their findings revealed significantly higher odds ratios for NAFLD as TG/HDL-C ratio tertiles increased. The highest TG/HDL-C ratio was associated with a three-fold increased risk of NAFLD.

There is no definitive cut-off point for the TG/HDL-c ratio in NAFLD in the literature. In one study based on ALT elevation for the determination of NAFLD, Di Bonito et al. (6) determined a high TG/HDL-C ratio as $>2$ and reported that this value was useful for predicting NAFLD in clinical practice. To the best of our knowledge, no other value has been recommended for NAFLD in the pediatric age group. In this study, we used a value of 2.27 for a high TG/HDL ratio. This value was also recommended by Giannini et al. (11) for predicting IR. In that study, the authors identified a close correlation between TG/HDL-C ratio and IR based on glucose clamp testing. Olson et al. (25) also demonstrated an association between TG/HDL ratio and QUICKI and HOMA in children and young adults. Our findings corroborate and extend these previous results by demonstrating this association with FGR, which can easily be employed in clinical practice. We hypothesized that the TG/HDL-C cut-off value of 2.27 recommended for IR might also be capable of use for NAFLD, due to the strong relationship between NAFLD and IR (26). On that basis, a TG/HDL-C ratio of $>2.27$ was shown to predict NAFLD with $64 \%$ sensitivity and $68 \%$ specificity. This cut-off also had a similar predictive value for IR (69\% sensitivity and 63\% specificity).

The predictive value of TG/HDL-C ratio in IR and NAFLD may be attributed to the close relationship between the two conditions. Expansion of visceral adipose tissue and resultant inflammatory cascade leads to IR. This process is considered the initial step in the development of NAFLD. IR triggers fatty acid deposition in the liver, and this gives rise to hepatic IR via subacute inflammation associated with the activation of the nuclear factor-kB pathway (4). NAFLD may therefore further promote elevated systemic $\mathrm{IR}$ and dyslipidemia, in turn resulting in accelerated atherosclerosis $(4,27)$.

One previous study of adults observed a relationship between TG-to-HDL-C ratio and elevated ALT and suggested that these were of evidential value in terms of NAFLD (28). One study in which this relationship was investigated in a pediatric population showed that the association between TG-to-HDL-C and ALT in obese children with NAFLD was independent of visceral adiposity and IR (6). In our study, consistent with these results, we also observed an association between TG-to-HDL-C ratio and elevated ALT.

The fact that liver biopsies were not employed as a standard tool in the diagnosis of steatosis represents a limitation of this study. However, ultrasonography is the most common diagnostic tool for identifying hepatic steatosis in clinical practice, and is also highly sensitive and specific in diagnosing fatty liver (26).

\section{Conclusion}

In conclusion, our study showed evidence that TG/ HDL-C was strongly associated with increased risk of NAFLD and IR. Considering the potential significance of NAFLD in terms of child health, it is important to check TG/HDL-C and if TG/HDL-C is elevated, especially TG/ HDL-C over 2.27, lifestyles modification is needed for preventing future NAFLD.

\section{Ethics}

Ethics Committee Approval: This study was approved by Haseki Training and Research Ethics Committee for Clinical Investigations (approval number: 359).

Informed Consent: It was taken.

Peer-review: Externally peer-reviewed.

\section{Authorship Contributions}

Surgical and Medical Practices: A.Ü., F.K. Concept: A.Ü., F.K. Design: A.Ü., N.S.D., M.E. Data Collection or Processing: A.H., F.K. Analysis or Interpretation: A.Ü., M.E. Literature Search: A.Ü., N.S.D. Writing: A.Ü.

Conflict of Interest: No conflict of interest was declared by the authors.

Financial Disclosure: The authors declared that this study received no financial support. 


\section{References}

1. Pacifico L, Chiesa C, Anania C, et al. Nonalcoholic fatty liver disease and the heart in children and adolescents. World J Gastroenterol 2014;20:9055-71.

2. Haslam DW, James WP. Obesity. Lancet 2005;366:1197-209.

3. Schwimmer JB DR, Behling C, Lavine JE. Fatty liver as a determinant of atherosclerosis. Hepatology 2005;42:610A.

4. Pacifico L, Nobili V, Anania C, Verdecchia P, Chiesa C. Pediatric nonalcoholic fatty liver disease, metabolic syndrome and cardiovascular risk. World J Gastroenterol 2011;17:3082-91.

5. Millan J, Pinto X, Munoz A, et al. Lipoprotein ratios: Physiological significance and clinical usefulness in cardiovascular prevention. Vasc Health Risk Manag 2009;5:757-65.

6. Di Bonito P, Moio N, Scilla C, et al. Usefulness of the high triglyceride-to-HDL cholesterol ratio to identify cardiometabolic risk factors and preclinical signs of organ damage in outpatient children. Diabetes Care 2012;35:158-62.

7. Nobili V, Alkhouri N, Bartuli A, et al. Severity of liver injury and atherogenic lipid profile in children with nonalcoholic fatty liver disease. Pediatric Res 2010;67:665-70.

8. Pacifico L, Bonci $E$, Andreoli G, et al. Association of serum triglyceride-to-HDL cholesterol ratio with carotid artery intimamedia thickness, insulin resistance and nonalcoholic fatty liver disease in children and adolescents. Nutr Metab Cardiovasc Dis 2014;24:737-43.

9. Sezer OB, Buluş D, Hızlı Ş, Andıran N, Yılmaz D, Ramadan SU. Low 25-hydroxyvitamin D level is not an independent risk factor for hepatosteatosis in obese children. J Pediatr Endocrinol Metab J Pediatr Endocrinol Metab 2016;29:783-8.

10. Kim-Dorner SJ, Deuster PA, Zeno SA, Remaley AT, Poth M. Should triglycerides and the triglycerides to high-density lipoprotein cholesterol ratio be used as surrogates for insulin resistance? Metabolism 2010;59:299-304.

11. Giannini C, Santoro N, Caprio S, et al. The triglyceride-to$\mathrm{HDL}$ cholesterol ratio: association with insulin resistance in obese youths of different ethnic backgrounds. Diabetes care 2011;34:1869-74.

12. Bundak R, Furman A, Gunoz H, Darendeliler F, Bas F, Neyzi O. Body mass index references for Turkish children. Acta paediatr 1992;95:194-8.

13. Marshall WA, Tanner JM. Variations in pattern of pubertal changes in girls. Arch Dis Child 1969;44:291-303.

14. Marshall WA, Tanner JM. Variations in the pattern of pubertal changes in boys. Arch Dis Child 1970;45:13-23.

15. Cook S, Auinger P, Huang TT. Growth curves for cardiometabolic risk factors in children and adolescents. J Pediatr 2009;155:S6.

16. National High Blood Pressure Education Program Working Group on High Blood Pressure in Children and Adolescents.
The fourth report on the diagnosis, evaluation, and treatment of high blood pressure in children and adolescents. Pediatrics 2004;114(Suppl 2 4th Report):555-76.

17. Keskin M, Kurtoglu S, Kendirci M, Atabek ME, Yazici C. Homeostasis model assessment is more reliable than the fasting glucose/insulin ratio and quantitative insulin sensitivity check index for assessing insulin resistance among obese children and adolescents. Pediatrics 2005;115:500-3.

18. Kurtoglu S, Akin L, Kendirci M, Hatipoglu N, Elmali F, Mazicioglu $\mathrm{M}$. The absence of insulin resistance in metabolic syndrome definition leads to underdiagnosing of metabolic risk in obese patients. Eur J Pediatr 2012;171:1331-7.

19. Expert Panel on Integrated Guidelines for Cardiovascular Health and Risk Reduction in Children and Adolescents; National Heart, Lung, and Blood Institute. Expert panel on integrated guidelines for cardiovascular health and risk reduction in children and adolescents: summary report. Pediatrics 2011;128(Suppl 5):213-56.

20. Di Bonito P, Sanguigno E, Di Fraia T, et al. Association of elevated serum alanine aminotransferase with metabolic factors in obese children: sex-related analysis. Metabolism 2009;58:368-72.

21. Stampfer MJ, Sacks FM, Salvini S, Willett WC, Hennekens CH. A prospective study of cholesterol, apolipoproteins, and the risk of myocardial infarction. N Engl J Med 1991;325:373-81.

22. McLaughlin T, Reaven G, Abbasi F, et al. Is there a simple way to identify insulin-resistant individuals at increased risk of cardiovascular disease? Am J Cardiol 2005;96:399-404.

23. Quijada Z, Paoli M, Zerpa Y, et al. The triglyceride/HDLcholesterol ratio as a marker of cardiovascular risk in obese children; association with traditional and emergent risk factors. Pediatr Diabetes 2008;9:464-71.

24. Kotronen A, Yki-Jarvinen H. Fatty liver: a novel component of the metabolic syndrome. Arterioscler Thromb Vasc Biol 2008;28:27-38.

25. Olson K, Hendricks B, Murdock DK. The Triglyceride to HDL Ratio and Its Relationship to Insulin Resistance in Preand Postpubertal Children: Observation from the Wausau SCHOOL Project. Cholesterol 2012;2012:794252.

26. Hamaguchi M, Kojima T, Takeda N, et al. The metabolic syndrome as a predictor of nonalcoholic fatty liver disease. Ann Intern Med 2005;143:722-8.

27. Targher G, Day CP, Bonora E. Risk of cardiovascular disease in patients with nonalcoholic fatty liver disease. N Engl J Med 2010;363:1341-50.

28. Sung KC, Ryan MC, Kim BS, Cho YK, Kim BI, Reaven GM. Relationships between estimates of adiposity, insulin resistance, and nonalcoholic fatty liver disease in a large group of nondiabetic Korean adults. Diabetes Care 2007;30:2113-8. 